\title{
Newtonia buchananii and its fungal decayers in natural stands
}

\author{
TUOMO NIEMELÄ and FRANK ANDERSON MREMA
}

\begin{abstract}
NIEMELÄ, T. \& MREMA, F.A. 2002: Newtonia buchananii and its fungal decayers in natural stands. - Karstenia 42: 49-66. Helsinki. ISSN 0453-3402.

Newtonia buchananii (Baker) G. Gilbert \& Boutique is a leguminous tree (Mimosaceae), an emergent in African moist forests, having its main distribution in southern central and eastern Africa. The characteristics and ecology of the tree are outlined. In natural forests the old, large $N$. buchananii individuals badly suffer of stem cracks and butt rot, caused by various fungi. In this paper decay-causing poroid Basidiomycetes (polypores) are dealt with. A new species, Phellinus newtoniae Niemelä \& Mrema, is described from material collected in the Mazumbai Forest Reserve, West Usambara Mts., and the Amani Forest Reserve, East Usambara Mts., Tanzania. It produces perennial, finally large basidiocarps in gaps between the buttresses of old, living Newtonia buchananii trees, being a serious butt-rot and trunk-rot causing pathogen of its host. It belongs to the $P$. rimosus (Berk.) Pilát complex which is taxonomically difficult; related taxa are compared, e.g., Phellinus lloydii (Cleland) G. Cunn., P. fastuosus (Lév.) Ryvarden, P. merrillii (Murrill) Ryvarden and P. swieteniae (Murrill) S. Herrera \& Bondartseva. Ganoderma boninense Pat., Fibroporia gossypium (Speg.) Parmasto and Phellinus sublaevigatus (Cleland \& Rodway) P.K. Buchanan \& Ryvarden are reported as new to East Africa. Twelve polypore species are dealt with, belonging to the genera Phellinus, Ganoderma, Fibroporia, Microporus and Perenniporia. Statistical data of the spore size variation is given for most species. The other fungal groups appearing on living Newtonia trees are briefly discussed.
\end{abstract}

Key words: Basidiomycetes, Newtonia, Phellinus, decay, East Africa, polypores, Usambara Mts., wood-rotting fungi

Tuomo Niemelä, Finnish Museum of Natural History, Botanical Museum, P.O. Box 47, FIN-00014 University of Helsinki, Finland

Frank Anderson Mrema, Tanzania Forestry Research Institute (TAFORI), Silviculture Research Centre, P.O. Box 95, Lushoto, Tanzania

\section{Introduction}

The genus Newtonia Baill. (Mimosaceae) includes a little over ten tree species in tropical Africa (Mabberley 1990); some Central African taxa have not yet been fully determined (Keay 1989). Newtonia buchananii (Baker) G. Gilbert \& Boutique is one of the emergent trees of the moist lowland and mid-altitude forests of East Africa. It has at least been reported from the East African countries of Uganda, Kenya, Tanzania, Rwanda and Burundi. In Central Africa it is found in Angola, southern Republic of the Congo,
Cameroon and Nigeria (Mambila Plateau), and in southern Africa in Malawi, Zambia, eastern Zimbabwe and central western Mozambique (Brenan 1959, Keay 1989, Lock 1989; map in White et al. 2001). It does not reach the Republic of South Africa (Coates Palgrave 1990, Wyk \& Wyk 1997).

With an altitudinal range from about 600 to 2130 metres (Brenan 1959), Newtonia buchananii is mainly distributed in the lower slopes of the Eastern Arc mountains: lowland rain forests and, in particular, submontane and lower montane forests of the hillsides. The Eastern Arc mountains 
which are under direct climatic influence of the Indian Ocean (Lovett 1996), are composed of ancient crystalline gneiss rocks, and extend from southern Udzungwa of Tanzania $\left(08^{\circ} 51^{\prime} \mathrm{S}, 34^{\circ} 49^{\prime}\right.$ E) to Taita Hills in Kenya $\left(03^{\circ} 25^{\prime} \mathrm{S}, 38^{\circ} 20^{\prime} \mathrm{E}\right)$. They are recognized for their high species diversity, the majority of which are endemic (Iversen 1991, Lovett 1996). Schulman et al. (1998) described and illustrated $N$. buchananii as it appears in old forests of East Usambaras, for instance in the Amani Nature Reserve.

The tree also occurs in fringing forests in the Zambesian Region (White 1983), extending into the peripheral rain forests south of the Equator. Newtonia buchananii is one of the most abundant tree species in Zambesian swamp forests, in areas where rainfall exceeds $1000 \mathrm{~mm}$ per year (Fanshawe 1971, White 1983). However, it seems to be missing from the peripheral semi-evergreen rain forests of West Africa. White et al. (2001) describe it as a Sub-Afromontane near-endemic.

Newtonia buchananii is a showy species of closed moist forests, found in rain forests usually along streams, and in groundwater forests, riv-

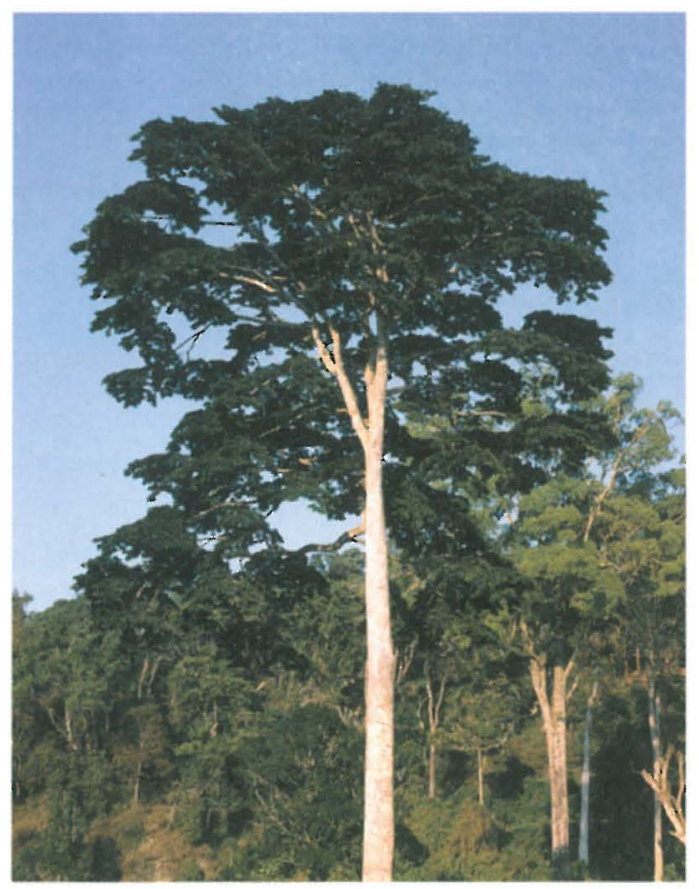

Fig. 1. An old Newtonia buchananii tree, left standing in a clearcut that was originally dense lower montane forest. Shume, West Usambara Mts., 9.XI.1987, photo TN. erine forests and swamp forests. In best sites it becomes a very large tree reaching more than 50 metres in height, with $200 \mathrm{~cm}$ in diameter (Redhead 1981). In the field, Newtonia trees can be recognized by their wide canopy with dark green and feathery foliage (Fig. 1), pole-like trunk with smooth bark, and tall and broad buttresses. The heartwood is beautifully red-coloured, and good for furniture and construction work (Bryce 1967).

Small seedlings of the Newtonia trees are commonly found in and around the forests, especially in open gaps within the rainforest of the Usambara Mountains. Growing mixed with smaller trees, old Newtonia individuals badly suffer of stem cracks and butt rot (Mrema \& Nummelin 1998). It seems that the mortality of large, old trees is accelerating due to fungal pathogens perhaps combined with environmental changes; their fall-down creates canopy gaps, e.g., in the Mazumbai Forest Reserve (West Usambara Mts., Tanzania). In near future mature trees may severely diminish in forest reserves and completely disappear from disturbed forests.

The patterns of injuries in Newtonia buchananii in the Mazumbai Forest Reserve were discussed and illustrated by Mrema and Nummelin (1998). It turned out that a wide variety of pathogens attack $N$. buchananii, and many fungi only appear as mycelia, making the identification difficult. The study of wood-inhabiting fungi in $N$. buchananii trees (30-60 $\mathrm{cm}$ in diam.) indicated that many fungal species inhabiting Newtonia do not belong to the basidiomycetes. Mycelia of Trichoderma were common, as well as endophytic fungi such as Amphisphaeria and Fusarium species (Suryanarayanan \& Rajagopal 2000). Many of these fungi were found within and next to a living sapwood. Other fungi of economic importance such as Nectria and Hypoxylon species were also present. Nsolomo and Venn (1996), while working in West Usambara and South Kilimanjaro (where habitats are also favourable for the tree), isolated 72 taxa from Ocotea usambarensis Engl., the majority $(83 \%)$ being non-basidiomycetous, while basidiomycetes contributed only with $17 \%$. While testing the ability of some fungi to cause decay in $O$. usambarensis, Nsolomo et al. (2000) recorded 16 non-basidiomycetes, including Trichoderma virens, as white rot fungi justified by their ability to produce lignin degrading enzymes. These authors reported non-basidiomycetes as pioneer decayer fungi in $O$. usam- 
barensis. In spite of the high total number of fungi involved, the main decayers are the polypores (basidiomycetous Aphyllophorales), being responsible of the greatest volume of wood degraded in living tree trunks. The primary pathogens of $N$. buchananii trees have remained largely unknown.

In this paper we list decay-causing polypores found by us in Tanzania. Previous papers in this series (Renvall \& Niemelä 1993, Niemelä et al. 1998) dealt with fungal decayers of two other East African trees, Ocotea usambarensis and Hagenia abyssinica (Bruce) J.F. Gmel. A part of the present paper was included in the $\mathrm{PhD}$ thesis of Mrema (2001).

\section{Materials and methods}

\section{Main study sites}

The Mazumbai Forest Reserve is situated in the West Usambara Mts., 0449' S, 38³0' E. To the south and west it is bordered by the Baga Forest Reserve (in which extensive uncontrolled cuttings have taken place), to the north by the Mazumbai estate and to the east by cleared cultivation land which still in the 1960 s was dense forest. With an area of ca. 400 hectares, the Mazumbai is one of the very few remaining areas of practically undisturbed forests that originally covered the whole West Usambara range. The description of the Mazumbai forest and the physical characteristics of the area are found in Lundgren (1978) and Redhead (1981). Main part of Mazumbai lies at the altitude of 1400-1500 m (lower half below the road) and 1500-1750 m (upper half), and hence the vegetation can be characterized as lower montane forest. The peak of the north-western corner of the Reserve, Sagara, lies just above $1900 \mathrm{~m}$, being covered by upper montane forest vegetation with twisted-trunked trees, abundant mossy and filmy-fern epiphytes and Erica heath scrub. Mean annual rainfall in the area is $1230 \mathrm{~mm}$ with a distinct wet season in April-May (Lundgren 1978), and so most part of the forest belongs to the wetter variant of the lower montane forests. Typical emergent trees are Allanblackia stuhlmannii (Engl.) Engl., Entandrophragma excelsum (Dawe \& Sprague)
Sprague, Isoberlinia scheffleri (Harms) Greenway, Newtonia buchananii and Parinari excelsa Sabine, and Ocotea usambarensis in the upper half. Wingfield (1975) has compiled a list of the plants found in Mazumbai.

Some collecting was carried out in Ndelemai Forest Reserve, in West Usambara Mts. between Mombo and Bumbuli, $04^{\circ} 53^{\prime} \mathrm{S}, 38^{\circ} 24^{\prime} \mathrm{E}$. The total area of the Reserve is 1346 hectares, but only less than $10 \%$ of it is unexploited. The terrain is steep to gentle hillsides. Altitude of that area is approximately $1500-1700 \mathrm{~m}$.

The Amani Nature Reserve lies in the heart of the East Usambara Mts., $05^{\circ} 06^{\prime} \mathrm{S}, 38^{\circ} 38^{\prime} \mathrm{E}$. The total area of the Reserve is 8380 hectares (Schulman et al. 1998), which includes over 1000 ha of forests owned by private tea companies. The Reserve also includes the Amani Botanical Garden which is one of the largest botanical gardens and arboretums in Africa. After many changes in history, and a danger of becoming extensively exploited in the 1980s, the legal status of the Amani Nature Reserve is now settled. The core area of ca. 300 hectares lies at the altitude between $400-1100 \mathrm{~m}$, and the annual rainfall may exceed $2000 \mathrm{~mm}$. The highest peak, Nilo, reaches $1506 \mathrm{~m}$. Because of lower mean altitude and much higher rainfall than in Mazumbai, the forest flora differs markedly, and can best be identified as submontane and lowland rainforest. Original forests of the East Usambaras are in general better preserved than those of West Usambara, although the population pressure is heavy and increasing also there. 217 indigenous trees (height over $10 \mathrm{~m}$ ) and 12 introduced ones are reported from East Usambara Mts. (Ruffo et al. 1989), growing in mixed, dense stands with no dominants. In addition to the trees listed for Mazumbai above, important large emergents are, e.g., Antiaris toxicaria Leschen, Cephalosphaera usambarensis (Warb.) Warb., Milicia (Chlorophora) excelsa (Welw.) C.C. Berg, Pouteria (Aningeria) adolfi-friedericii (Engl.) Meeuse, Schefflerodendron usambarense Harms, and Syzygium guineense (Willd.) DC. The best source for the trees in Amani is Schulman et al. (1998), and general information is presented by Hamilton \& Bensted-Smith (1989) and Iversen (1991). 


\section{Collecting}

Fieldwork was made mostly by the author Mrema (abbreviated FAM) in the Mazumbai Forest Reserve, West Usambara Mts., and the Amani Forest Reserve, East Usambara Mts., Tanzania, during the years 1998-2000. The author Niemelä (TN) also visited the areas and collected fungi there during several periods in 1971-2000; in $1995 \mathrm{Mr}$ Jarmo Honkanen (JH; Helsinki), among others, participated and collected polypores in the area. Basidiocarps of polypores were commonly noted on the bark of living Newtonia trees between buttresses. Some were collected on attached and fallen branches. Collecting of specimens was made by cutting sections from large basidiocarps, while smaller ones were taken complete, and keeping them separately in paper bags. The position of collection, the condition of host tree and other features were recorded, and collections were numbered. Over $80 \%$ of the collected polypores were obtained from living trees. Specimens were dried with a mushroom dryer: an aluminium box with shelves of perforated plates, heated to $60 \pm 2^{\circ} \mathrm{C}$ using two hurricane lamps below the lowermost shelf. After drying, two sets of voucher specimens were kept at the Lushoto Herbarium, and duplicates were forwarded for identification in the Botanical Museum of the University of Helsinki, Finland. A number of pure cultures were isolated by FAM from decaying Newtonia trees for future studies.

\section{Identification}

Laboratory work with a microscope was mostly made by TN; JH and Dr Pertti Renvall (Kuopio) identified a smaller number of collections. When studying fungal basidiocarps, sections were mounted primarily in Cotton Blue (abbreviated as CB): $0.1 \mathrm{mg}$ aniline blue (Merck 1275) dissolved in $60 \mathrm{~g}$ pure lactic acid; $\mathrm{CB}+$ means cyanophily, CB- acyanophily. Spore and other measurements were made in that medium. Amyloid (bluish grey or purplish grey) and dextrinoid (reddish brown) colour reactions are obtained with Melzer's reagent (IKI): $1.5 \mathrm{~g}$ KI (potassium iodide), $0.5 \mathrm{~g} \mathrm{I}$ (crystalline iodine), $22 \mathrm{~g}$ chloral hydrate, aq. dest. $20 \mathrm{ml}$; IKI- means neither amyloid nor dextrinoid reaction. Occasionally also $5 \%$ $\mathrm{KOH}$ was used in microscopy.

As a rule 30 spores were measured from each specimen selected for a closer scrutiny. In presenting the variation of spore size, $5 \%$ of the measurements out of each end of the range are given in parentheses. $\mathrm{L}=$ mean length (arithmetical mean of all spores), $W=$ mean width, $\mathrm{Q}=$ extreme values of the length/width ratios among the studied specimens, and $\mathrm{n}=$ the number of spores measured from given number of specimens. In some critical Phellinus species also hyphal thicknesses and the dimensions of setae are calculated in a similar accuracy. Many of the species are described here in a fairly detailed way, in spite of the presence of up-to-date descriptions in the literature. Exact spore measurements, for instance, are needed in future when deciding the species limits of widespread tropical taxa, many of them certainly being quite collective so far.

In the identification the standard reference book used was Ryvarden \& Johansen (1980), and for identifying Phellinus species Larsen \& Cobb-Poulle (1990), Dai
(1999) and Núñez \& Ryvarden (2000) were the most useful ones. Collections of the Herbarium $\mathrm{H}$ and others, separate papers, and other sources were used as needed. Herbarium abbreviations are according to Holmgren et al. (1990); specimens listed with no mention on herbarium are preserved in H. Colour terms are mostly according to Anonymous (1969), Rayner (1970) and Petersen (1996).

\section{Species of the Phellinus rimosus complex}

Phellinus newtoniae Niemelä \& Mrema, spec. nova - Figs. 2-3

Carpophorum perenne, fuscum, cum poris 5-8 per mm; systema hypharum dimitica, setae nullae, sporae brunneolae, globosae, 5.1-5.9 $\times$ 4.5-5.4 $\mathrm{mm}$.

Holotypus: Tanzania. Tanga Region, Lushoto Dist., West Usambara Mts., Mazumbai Forest Reserve, on living Newtonia buchananii at base between buttresses, 10.I.1998 F.A. Mrema T26/ $14(\mathrm{H})$.

Basidiocarps perennial, sessile, usually 10$25 \mathrm{~cm}$ wide (finally much wider), $3-5 \mathrm{~cm}$ thick or more at base, projecting 5-15 cm. Upper surface matted, at first warted or with roundish knots or even minute secondary pilei arising from the main pileus, dark clay-buff, snuff brown, umber or rusty tawny, later becoming more blackish but matted even then, zonation indistinct. Edge of pileus fairly thin (but not sharp) in fully grown specimens, but thick and rounded in luxuriantly growing young basidiocarps. Lower surface cinnamon brown, fairly smooth, pores (5-)6-8 per $\mathrm{mm}$, round but unevenly distributed, tube mouths entire. Section: Context radially fibrous especially at base and with 1-2 or no concentric zones, hard, when young golden yellow, with strong metallic sheen, older cinnamon but also then with silky lustre on broken surface, contextual layer 2-5(-10) mm; no crust, no indurated surface in old parts; tube layer stratified, equally hard as context and of the same colour.

Hyphal system dimitic (in context indistinctly), all septa without clamp connections. Trichoderm of young (first 2-4 years' growth) upper surface made of obliquely uprising tips of skeletal hyphae, apically frequently septate, sometimes with moniliform constrictions or swollen up to 5.5-9.5 $\mu \mathrm{m}$, with no encrustations and making a spaced texture, pale yellow-brown, at tips $\mathrm{CB}+$, fairly thick-walled. Context dimitic but with nu- 

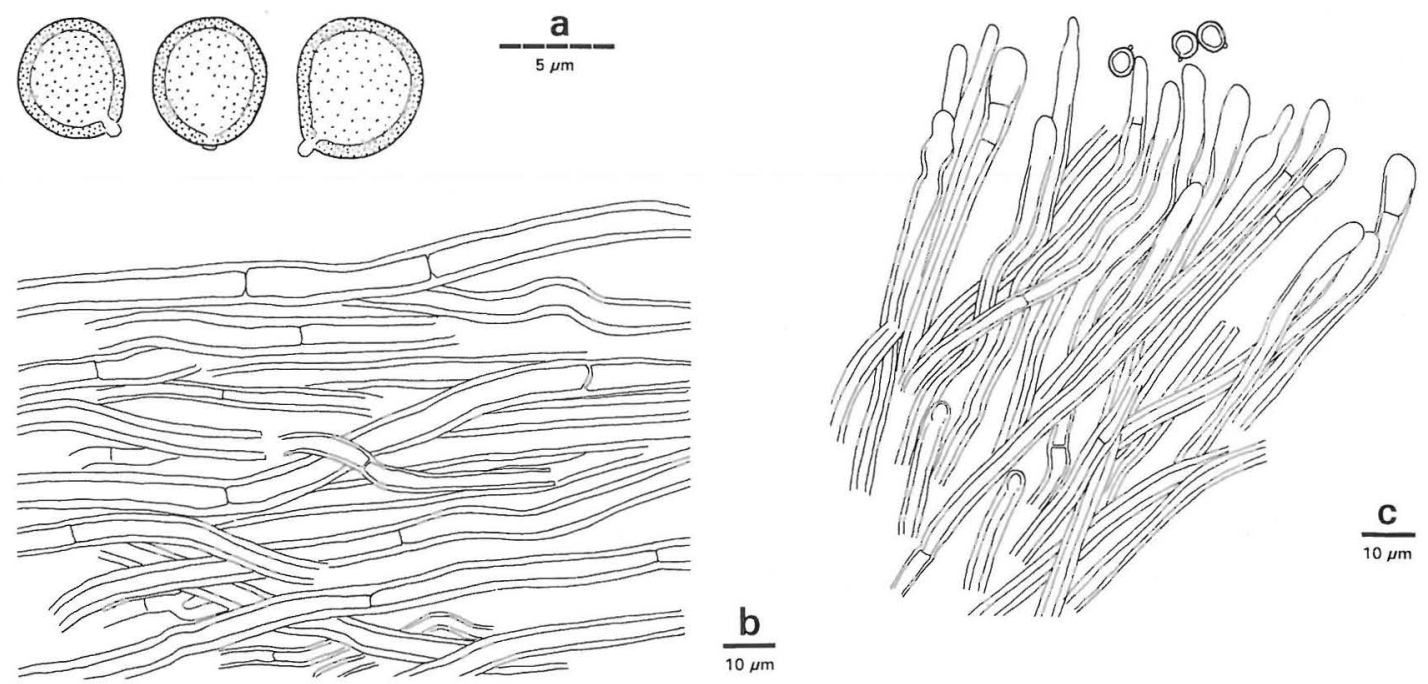

Fig. 2. Phellinus newtoniae Niemelä \& Mrema. a) spores, b) context, c) trichoderm. Drawn in CB from holotype.

merous transitional hyphae; typical skeletal hyphae parallel with radial orientation, (3.4-)4.17.3(-9) $\mu \mathrm{m}$ in diam. $(\mathrm{n}=140 / 5)$, fairly thick-walled but with very wide lumen, occasionally with a lens- or medallion-like swelling, distinctly and frequently septate, in $\mathrm{CB}$ yellow-brown with green tint, brownish yellow in IKI, in $\mathrm{KOH}$ hyphal walls turn cherry red and thicken somewhat (wall thickness then up to $2 \mu \mathrm{m}$ ). Generative hyphae thin-walled, hyaline or yellow-walled and septate, branched, twisted and freely oriented, transitions towards skeletal hyphae common. Trama distinctly dimitic, skeletal hyphae (2.7-)3$4.5(-4.8) \mu \mathrm{m}$ in diam. ( $\mathrm{n}=130 / 5)$, thick-walled, with a capillary lumen, interwoven but with longitudinal orientation, orange-brown in $\mathrm{CB}$, yellowbrown in IKI, cherry red in $\mathrm{KOH}$ and walls then thickening inwards so that hyphae are subsolid; generative hyphae thin-walled, hyaline or pale yellow in all media, 2-3 $\mu \mathrm{m}$ in diam. Dissepiment edge dominated by variably oriented skeletal hyphae; no encrusted generative hyphae.

Hymenium: Basidia obovoid or barrel-shaped, ca. $9 \times 4.5 \mu \mathrm{m}$, four-sterigmate; basidioles similar and about the same size; no setae, no cystidia.

Basidiospores subglobose, (4.8-)5.1-5.9(-6.3) $\times(4.4-) 4.5-5.4(-5.8) \mu \mathrm{m}, \mathrm{L}=5.42 \mu \mathrm{m}, \mathrm{W}=4.87 \mu \mathrm{m}$, $\mathrm{Q}=1.09-1.15(\mathrm{n}=120 / 4)$; spore wall thick, pale brown in $\mathrm{CB}$, yellow-brown in IKI, red-brown in $\mathrm{KOH}$, young and still hyaline spores $\mathrm{CB}+$.

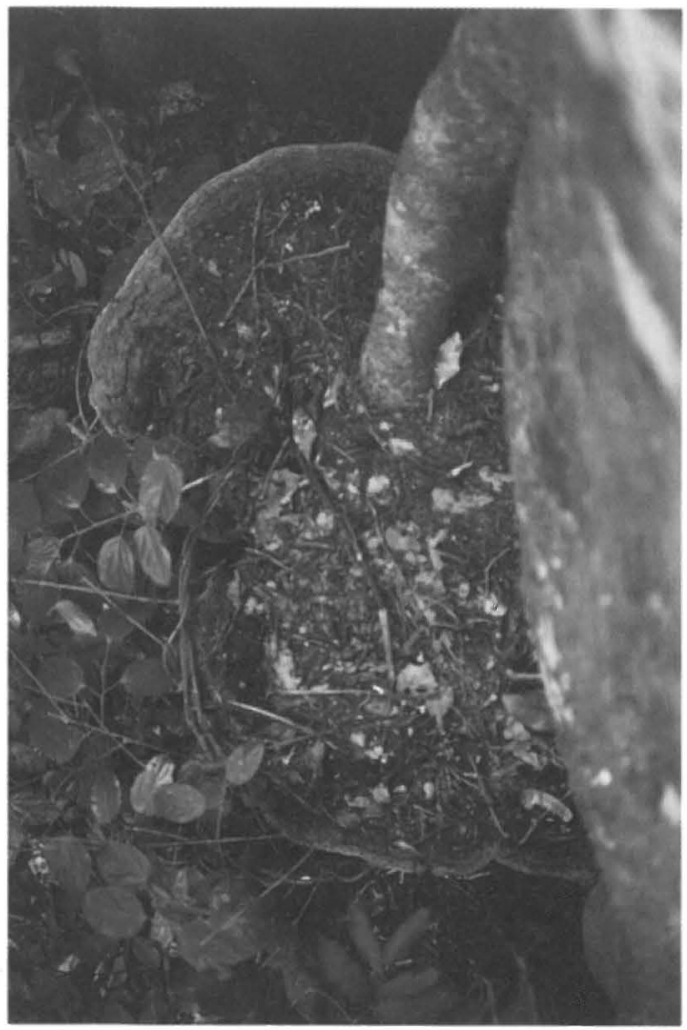

Fig. 3. Old basidiocarp of Phellinus newtoniae Niemelä \& Mrema at the base of Newtonia buchananii. Mazumbai, 15.XII.1995 Honkanen 793, photo TN. 
Specimens studied: On Newtonia buchananii: Tanzania. Tanga Reg., Muheza Dist., Amani - Derema, at base of living tree in open forest, 22.II.2000 Mrema Al/ $5 a$; Nilo - Amani, Forest Reserve, on trunk of living tree, 25.II.2000 Mrema A15/19a; on trunk of living tree, basidiocarp $30 \mathrm{~m}$ high up, 6.III.2000 Mrema A13/ 12. Lushoto Dist., Mazumbai, at base of big living tree, 15.XII.1995 Honkanen 798; at base between buttresses of living tree, 9.I.1998 Mrema T6/3, 10.I.1998 Mrema $T 14 / 10, T 26 / 14$; at base of tree with 24 buttresses, 12.I.1998 Mrema T41/20; buttress of living tree, 8.III.2000 Mrema M2/6; on living buttress and fallen branches, 8.III.2000 Mrema M3/9a; $0.5 \mathrm{~m}$ high up on living tree trunk, 8.III.2000 Mrema M4/4a; between buttresses of living tree, 8.III.2000 Mrema M9/1; bottom of living tree, 8.III.2000 Mrema M12/2; on fallen dead branches under living tree, 8.III.2000 Mrema M13/ $4 b$; stem of a living tree, 8.III.2000 Mrema M17/10; between buttresses of living tree, 8.III.2000 Mrema M20/16; trunk of living tree, 10.III.2000 Mrema M10/ $15 b$. - Untypical specimens (not paratypes): Mazumbai, at base between buttresses, 10.I.1998 Mrema T11/7, T28/15.

Collection from another host: Tanzania. Tanga Reg., Lushoto Dist., Mazumbai, at base of living Agarista (Agauria) salicifolia, 10.XII.1989 Niemelä 5285 et al.

\section{Notes on Phellinus newtoniae}

Initial stage of this species is a hemispherical umbo, which may be fairly large. When fully grown it produces large but fairly thin basidiocarps, but the edge is somewhat rounded and not sharp. The matted upper surface of young pilei is brown with a faint vinaceous tint. Basidiocarps are mostly found at the bases of big, old Newtonia trees; such trees already have prominent buttresses, and the fungus emerges in between them. Basidiocarps were also collected high up $(30 \mathrm{~m})$ on the trunk of standing, living tree. Host trees usually had a distinct butt rot and often also stem cracks. All this makes a strong evidence that $P$. newtoniae is a serious pathogen, decaying Newtonia trees.

The two untypical specimens mentioned above are large (projecting up to $25 \mathrm{~cm}$ ) and very thick (up to $10 \mathrm{~cm}$ ) also in their pileus outside the umbonate base. Colours and the golden yellow, metallic, fibrous structure of the context agree with typical $P$. newtoniae, but pores are smaller (7-10 per mm) and skeletals of the context less thick (mostly 3.9-5 $\mu \mathrm{m}$ in diam.). Evidently these are just old basidiocarps of the species, but we did not include them in the description of the species.

If identified according to some recent manuals of the genus (e.g., Larsen \& Cobb-Poulle 1990,
Dai 1999), this polypore will key out as Phellinus lloydii (Cleland) G. Cunn., a species described from Australia (Cleland 1935). Its isotype was studied (Australia: South Australia Dist., National Park, 6.VIII.1921 Cleland, PDD 7119). Externally it is fairly similar, perennial; context is golden brown and lustrous like in Phellinus robustus (P. Karst.) Bourdot \& Galzin (=Fomitiporia robusta (P. Karst.) Fiasson \& Niemelä); pores are round, 5-6 per mm. There is no crust in the type specimen. In the microscope there are differences, however. Phellinus lloydii is distinctly monomitic with yellow-brown hyphae, $\mathrm{CB}+$, thick-walled in all parts and frequently simple-septate. In $\mathrm{KOH}$ the walls of skeletal hyphae thicken strongly both out- and inwards, and some sections of the hyphae in context turn abruptly very thickwalled and swollen. The spores of $P$. lloydii are broad ellipsoid or subglobose, (4.9-)5-5.5(-5.6) $\times(3.9-) 4-4.7(-4.9) \mu \mathrm{m}, \mathrm{L}=5.20 \mu \mathrm{m}, \mathrm{W}=4.36 \mu \mathrm{m}$, $\mathrm{Q}=1.19(\mathrm{n}=30 / 1)$, i.e. narrower than in P. newtoni$a e$, though the difference is small.

Phellinus merrillii (Murrill) Ryvarden resembles the new species in many respects. Lectotype of Pyropolyporus merrillii Murrill was studied (Philippines: Culion Island, XII.1902 E.D. Merrill 3570, NY 148). It has larger pores (4-5 per $\mathrm{mm}$ ) than in our species; spores are ellipsoid, about the same length but $1 \mu \mathrm{m}$ narrower, in the type (4.6-)4.7-5.4(-5.7) $\times(3.6-) 3.7-4.1(-4.4) \mu \mathrm{m}$, $\mathrm{L}=5.10 \mu \mathrm{m}, \mathrm{W}=3.89 \mu \mathrm{m}, \mathrm{Q}=1.31(\mathrm{n}=60 / 1)$. Context of $P$. merrillii is dark reddish brown, darker than in $P$. newtoniae; it is compact and very hard in some zones. Context is dimitic with interwoven texture; skeletals are reddish brown, (2.5-)3.3$4.5(-4.8) \mu \mathrm{m}(\mathrm{n}=30 / 1)$ in diam. (i.e., not yellowish as in $P$. newtoniae, and distinctly narrower), becoming bright brownish red in $\mathrm{KOH}$ but not changing much in other respects. Especially in squash mounts made on $\mathrm{KOH}$ the dense areas of the context look like trimitic: in addition to generative and skeletal hyphae there are arboriform hyphae, brown, thick-walled, with branches 2-3 $\mu \mathrm{m}$ in diam., reminding the binding hyphae. Their true nature is not known, but they may be senescent generative hyphae: in many Phellinus sensu lato the hyphal walls (as well as walls of spores that were trapped inside the mycelium-filled tubes) swell and absorb brown pigment from surrounding skeletal hyphae. No doubt the two species are related. Recent descriptions of P. merrillii are found in Ryvarden \& Johansen (1980), 
Gilbertson \& Ryvarden (1986), Quanten (1997) and Dai (1999). The concept of the species may be collective: for instance, up to 10 pores per $\mathrm{mm}$ have been reported.

Phellinus fastuosus (Lév.) Ryvarden is also related; see its description and discussion below. Spores are similar in the two. Differences are seen in the pore size, $9-10$ pores per $\mathrm{mm}$ in the type of $P$. fastuosus, and in its very hard consistency and well-developed crust. Hyphal tips on young crust of $P$. fastuosus are short, thick-walled and regularly narrow, not swollen/septate and making a spaced trichoderm like in $P$. newtoniae.

Phellinus sublinteus (Murrill) Ryvarden (= Aurificaria luteoumbrina (Romell) D.A. Reid) has soft corky basidiocarps, and its spores are smaller, 4-5 × 3.5-4.5 um (Ryvarden \& Johansen 1980, Gilbertson \& Ryvarden 1986).

Pyropolyporus troyanus Murrill (= Phellinus nilgheriensis (Mont.) G. Cunn., according to Ryvarden 1985) was studied from its type from Jamaica: Cocpit Co., Troy and Tyre, 12-14.I.1909 Murrill \& Harris 980 (NY). It is paler coloured in section, and has grey and smooth crust on its sulcate surface; spores are smaller, (4.3-)4.4-5 $(-5.2) \times(3.7-) 3.8-4.4(-4.6) \mu \mathrm{m}, \mathrm{L}=4.73 \mu \mathrm{m}$, $\mathrm{W}=4.06 \mu \mathrm{m}, \mathrm{Q}=1.17(\mathrm{n}=30 / 1)$ and, in particular, its skeletals are narrow like in Phellinus allardii (Bres.) S. Arnold, mostly 2.5-3.5 $\mu \mathrm{m}$ in diam.

The context of the type of $P$. swieteniae (Murrill) S. Herrera \& Bondartseva (Cuba, Santiago de Cuba Prov., Alto Cedro, stump of mahogany, 1920.III.1905 Earle \& Murrill 545, NY) is golden yellow like in our material from Newtonia, and in Phellinus robustus, very thick, well over $10 \mathrm{~cm}$ in the type specimen. The type specimen was illustrated by Lowe (1957:21, scale indicated wrongly, should be $\times 1 / 4)$. Spores are brownish, thickwalled, (4.5-)4.7-5.3(-5.5) ×(3.6-)3.7-4.3 $\mu \mathrm{m}, \mathrm{L}=$ $4.94 \mu \mathrm{m}, \mathrm{W}=4.00 \mu \mathrm{m}, \mathrm{Q}=1.24(\mathrm{n}=30 / 1)$, i.e., clearly smaller than in $P$. newtoniae. Skeletal hyphae of the context are slightly thinner than in our material, (3.1-)3.3-4.3(-4.7) $\mu \mathrm{m}$ in diam. $(n=30 / 1)$ and tramal hyphae are equal in the two.

\section{Phellinus cf. rimosus (Berk.) Pilát}

Basidiocarps perennial, umbonate for many first years, finally very thick triquetrous, up to $20 \mathrm{~cm}$ wide, $15 \mathrm{~cm}$ thick (triquetrous basidiocarps $8 \mathrm{~cm}$ ), projecting 10-14 cm. Upper surface at an um- bonate stage matted, golden yellow, smooth; in older pilei greyish brown, matted and with $2-4 \mathrm{~cm}$ broad, sulcate zones; finally rimose with easily detached, indurated, black, thick blocks. Edge of pileus rounded and very thick, golden yellow, matted. Lower surface non-poroid for very many first years, resembling the edge in its colour and texture; poroid area eventually developing, slightly darker brown than the edge, pores round, 6-8 per mm. Section: No crust on upper surface; context very thick $(7-10 \mathrm{~cm}$ or more in umbonate specimens, $4-5 \mathrm{~cm}$ in projecting pilei), yellow-brown or brass-coloured, matted or with only faint silky lustre on surfaces split when fresh, very hard and (when cut) somewhat brittle in dry condition; with dense and clear concentric growth zones; tube layer concolorous, only a few $\mathrm{mm}$ thick in umbonate specimens, thicker but indistinctly layered in old projecting pilei.

Hyphal system dimitic with clear difference between typical generative and skeletal hyphae, but intermediary hyphae also commonly seen; no clamps. Tomentum of young (1-2 yrs) surface composed of tufts of unswollen tips of skeletal hyphae (trichoderm); no cuticle or crustose layer; old surface indurated in variable depth. Context with radially oriented, brown, thick-walled, CB-, fairly narrow skeletals, (2.2-)2.7-4.2(-4.9) $\mu \mathrm{m}(\mathrm{n}=90 / 3)$, and randomly oriented generative and intermediary hyphae, all kinds of hyphae septate (skeletals only occasionally). Trama distinctly dimitic, skeletals subparallel, thick-walled, narrow, (2.2-)2.5-3.4(-3.6) um $(\mathrm{n}=90 / 3)$, only rarely septate and brown in colour. Dissepiment edge with variably oriented skeletals and generative hyphae; no encrusted hyphal tips.

Hymenial structures poorly preserved in our material, but evidently made of basidia and basidioles only; no setae, no cystidia.

Basidiospores subglobose, brown, (5.1-)5.3$6(-6.2) \times(4.4-) 4.7-5.5(-5.6) \mu \mathrm{m}, \mathrm{L}=5.61 \mu \mathrm{m}, \mathrm{W}=$ $5.09 \mu \mathrm{m}, \mathrm{Q}=1.09-1.12(\mathrm{n}=90 / 3)$; spore wall thick, pale brown in CB (i.e., CB-), yellow-brown in IKI (contents reddish), red-brown in $\mathrm{KOH}$.

Specimens studied: On Newtonia buchananii: Tanzania. Tanga Reg., Lushoto Dist., Mazumbai Forest Reserve, at base between buttresses, 10.I.1998 Mrema T23/ 12; human-disturbed forest, at base between buttresses, 11.I.1998 Mrema T38/18, 12.I.1998 Mrema T43/21; branches at about $16 \mathrm{~m}$ from ground, 12.I.1998 Mrema T44/22. 
Specimens of Phellinus rimosus studied for comparison (not included in the description above): Kenya. Coast Prov., Taita Dist., Tsavo East National Park, near Voi Gate, standing dead tree in open savanna, 15.I.1971 Niemelä $417 a$. Zambia. Southern Prov., Livingstone Dist, $100 \mathrm{~km}$ W of Livingstone town and falls, on living Colophospermum mopane, 13.II.1988 Niemelä 4162.

\section{Notes on Phellinus cf. rimosus}

It seems that the luxuriantly growing, young stage of this fungus has not been described before.

This species is characterized by yellow (young) or yellowish brown (old), very robust basidiocarps, in which the context initially assumes most of the thickness. The context is characterized by dense concentric zones; it is very hard in dry condition, but brittle when cut. It remains as a large, hemispherical knot for very many first years, but basidiocarps become finally strongly projecting, triquetrous and rimose on their upper surface. Our material closely resembles typical Phellinus rimosus, but some differences are discussed below. There are conflicting opinions on the correct name of the species (cf. Kotlaba \& Pouzar 1978).

The initial knot-like stage of our material differs strikingly from typical $P$. rimosus, but hyphal characteristics reveal the identity, and similarities appear when the basidiocarps grow older. Our collections from Newtonia have more pores per mm (6-8) than typical $P$. rimosus (4-6), and thicker and more yellow context. Phellinus rimosus is usually found in dry, exposed localities, such as savanna woodlands of East Africa, mopane woodlands of Zambia and Namibia, and the Mediterranean. Our material derives from humid montane vegetation belt, albeit from human-disturbed, thinned forests where sunshine may be quite hot during spells of drought.

In the microscope the spores are almost identical, in our Kenyan and Zambian specimens (5.2-)5.3-5.9(-6) × (4.2-)4.6-5.1(-5.3) $\mu \mathrm{m}, \mathrm{L}=$ $5.66 \mu \mathrm{m}, \mathrm{W}=4.84 \mu \mathrm{m}, \mathrm{Q}=1.17(\mathrm{n}=60 / 2)$. Context hyphae are equally narrow in the two, as well as the skeletals of tube trama, but in typical P. rimosus the tramal hyphae are more interwoven (subparallel in our material from Newtonia).

Narrow skeletals link Phellinus rimosus with $P$. allardii, but externally the two are very different (see Núñez \& Ryvarden 2000 for a description of $P$. allardii), and the latter has smaller spores.
Pyropolyporus troyanus (see above) has narrow skeletal hyphae, too, but its basidiocarp has a sharp edge, very thin context layer (a few mm only), and cinnamon brown colours in section; it has a cigar brown to greyish crust, making the pileus sulcate with narrow smooth zones.

Collections from living Newtonia trees prove this polypore to be a harmful pathogen, at least of old tree individuals, having up to 19 buttresses. In host trees a distinct butt rot was observed. The finds originate from human disturbed forests.

\section{Phellinus fastuosus (Lév.) Ryvarden}

Basidiocarps perennial, shelf-shaped or triquetrous, very hard, broadly attached, up to 18 $\mathrm{cm}$ wide, $6 \mathrm{~cm}$ thick, projecting 6-10 $\mathrm{cm}$ (old basidiocarps evidently much larger). Upper surface cigar brown, sepia or black-brown, sulcate with narrow zones, glabrous from the beginning and covered with hard crust; old parts eroded and rough, cracked only a little. Edge of pileus thin and sharp, regular, dark cinnamon. Lower surface dark cinnamon brown, with slight silky sheen when turned in incident light, pores round, 6-8 per mm. Section: Crust on the surface ca. $1 \mathrm{~mm}$ thick; context layer thin in relation to tube layer, dark cinnamon, with slight silky sheen on broken surface, thicker context of the base often with crustose layers also deeper in; tubes concolorous, seasonal layers distinct.

Hyphal system dimitic; no clamps. Crust present on surface already in first year's growth zone, composed of tightly interwoven skeletal hyphae; hyphal tips short, thick-walled, of even thickness. Context with radially oriented, yellowbrown, thick-walled (wall often $>2 \mu \mathrm{m}$ ), occasionally septate skeletals, (3.1-)4-7.5(-8.4) $\mu \mathrm{m}(\mathrm{n}=$ $80 / 3$ ), and randomly oriented generative and intermediary hyphae. Trama distinctly dimitic, skeletals interwoven, thick-walled, $(2.8-) 3-4.4(-4.8)$ $\mu \mathrm{m}(\mathrm{n}=80 / 3)$, only rarely septate and brown in colour; generative hyphae 2-3 $\mu \mathrm{m}$, thin-walled, hyaline in all media. Dissepiment edge with variably oriented skeletals and generative hyphae; no encrusted hyphal tips.

Hymenium with basidia ca. 9-10 $\times 4-5 \mu \mathrm{m}$ and fairly similar basidioles; no setae, no cystidia.

Basidiospores subglobose, brown, (4.9-)5.1$5.8(-6.1) \times(4.4-) 4.5-5.2(-5.4) \mu \mathrm{m}, \mathrm{L}=5.39 \mu \mathrm{m}$, $\mathrm{W}=4.87 \mu \mathrm{m}, \mathrm{Q}=1.09-1.13(\mathrm{n}=90 / 3)$; spore wall thick, $\mathrm{CB}-$ (very young hyaline and $\mathrm{CB}+$ ). 
Our Tanzanian material agrees with the type specimen of $P$. fastuosus. Basidiocarps of this species are much harder, both to break and to cut, than in the other species of the complex, and the colour of the context is darker. The species is quite common in East Africa (Ryvarden \& Johansen 1980). It does not seem to be harmful to Newtonia buchananii, as it mostly grows on dead branches, either fallen-down or still attached.

Isotype of Fomes fastuosus Lév. was studied (Singapore, coll. 1837 Gaudichaud 19520, BPI US0308414, S F15665). The material is very fragmentary, but luckily consists of tubes, context and upper surface. Spores are globose and brown, very much like in the other species of the complex, (5.1-)5.2-5.7(-6.1) ×(4.6-)4.7-5.3(-5.4) $\mu \mathrm{m}, \mathrm{L}=$ $5.48 \mu \mathrm{m}, \mathrm{W}=4.97 \mu \mathrm{m}, \mathrm{Q}=1.10(\mathrm{n}=30 / 1)$. The skeletals are in the context of $P$. fastuosus (3.1-)4-6 $(-6.8) \mu \mathrm{m}(\mathrm{n}=30 / 1)$ and in trama (3.4-)3.5-4.5 (-4.8) $\mu \mathrm{m}(\mathrm{n}=30 / 1)$. All these measurements from the type were also included in the species description above. The crust is glassy black in section, $0.2 \mathrm{~mm}$ thick and sharply delimited even close to the pileus margin, made of interwoven skeletals, tightly packed but anyhow easily seen in both IKI and $\mathrm{CB}$; surface consists of narrow and finger-like, thick-walled, $\mathrm{CB}+$, hyphal ends pointing in all directions.

Specimens studied: On Newtonia buchananii: Tanzania. Tanga Reg., Lushoto Dist., Mazumbai, at base between buttresses, 10.I.1998 F.A. Mrema T29/15; fallen branch, 8.III.2000 Mrema M8/9b, M14/7a.

All the species treated above belong to the Phellinus rimosus complex. It is equal to Section D in the key of Núñez and Ryvarden (2000: 95), and approximately the same as Phellinus subg. Fulvifomes (Murrill) Y.C. Dai., but Dai (1999) included in it also many setae-bearing taxa. Most members of this group are tropical - warm temperate (meridional) in their distribution. They have broad ellipsoid to subglobose, thick-walled and brown spores, no setae, and no crystal-bearing generative hyphae at tube mouths.

In the Phellinus rimosus complex the average diameter of tramal and contextual skeletals, and the colour of the latter are important characters for identification, while spores offer little help. The colour and texture of the context are important, too, but they should be studied from broken surfaces, preferably made before drying. In saw- cut surfaces most of the important characters are lost. Some species have a crust, seen in a section as a differentiated layer covering young (1-3 years old) surface; others have a compact trichoderm, seen in the microscope as upright-oriented hyphae ending in tufts or separate hyphal tips. Although the group is easily outlined, species differentiation is troublesome and often made according to macroscopy only. Certainly this is one of the most difficult groups within the collective genus Phellinus, even more so because many of the type specimens are badly preserved and lack important characters. A revision would be needed, supported by interfertility tests and molecular studies; it would be desirable to first settle the number of species, their characteristics and names within one coherent area (continent), before expanding the study into a wider area. It seems that at present many of the widely used names are understood collectively, and the complex may contain a very high number of species, specialized to live on specific tree genera and families, or occurring in restricted geographical areas only.

\section{Other fungi collected on Newtonia}

\section{Phellinus callimorphus (Lév.) Ryvarden - Fig. 4}

Basidiocarp perennial, thin and flat or conchate, hard, usually ca. $5 \mathrm{~mm}$ thick (seldom $1 \mathrm{~cm}$ or more). Upper surface velvety or matted, cigar brown, sulcate with narrow zones, finally eroded and rough but without crust. Edge thin and sharp; sterile margin of the underside distinct, somewhat swollen, 1-2 mm broad. Pore surface dark umber brown, with silky lustre, pores round, 8-10 per mm. Section: Context $1-3 \mathrm{~mm}$, soft woody, homogeneous, cinnamon or clay buff, with no distinct sheen on split surface; tubes slightly paler.

Hyphal system dimitic, generative hyphae simple-septate, thin-walled and hyaline; skeletal hyphae thick-walled, yellow-brown, with occasional septa, red-brown in $\mathrm{KOH}$ but otherwise unchanged, fairly parallel in context $(2.8-4 \mu \mathrm{m}$ in diam.) and trama (2.3-3.1 $\mu \mathrm{m})$; parallel arrangement is somewhat obscured because of messy intermixing hyphae. No cystidia; some basidioles having a conical apex and so resembling cystidioles. Crystal-bearing hyphae present (especially in non-fertile specimens) at tube mouths, and 


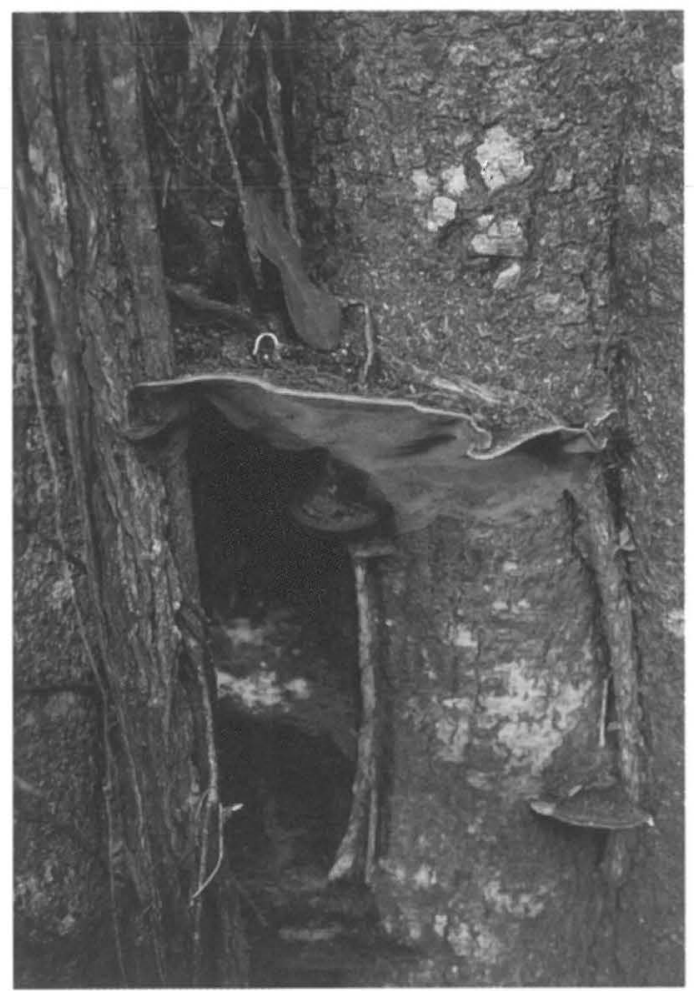

Fig. 4. Phellinus callimorphus (Lév.) Ryvarden, basidiocarps at the base of Newtonia buchananii. Mazumbai, 15.XII.1995 Honkanen 783, photo TN.

skeletal hyphae strictly parallel there. Hymenial setae brown, subulate, or ventricose with narrow and sharp-pointed apex and moderately swollen 'belly', often with deformed base, (21-)23-30 $(-33) \times(5-) 5.5-7(-8) \mu \mathrm{m}, \mathrm{L}=26.01 \mu \mathrm{m}, \mathrm{W}=6.09$ $\mu \mathrm{m}, \mathrm{Q}=3.98-4.52(\mathrm{n}=28 / 5)$.

Basidiospores ellipsoid, thin-walled, hyaline, often with a 'forehead' (apiculus arising not from the proximal apex but closer to the ventral side), IKI-, CB-, (3.3-)3.5-4.3(-4.5) ×2.4-3.1(-3.3) $\mu \mathrm{m}, \mathrm{L}=4.01$ $\mu \mathrm{m}, \mathrm{W}=2.83 \mu \mathrm{m}, \mathrm{Q}=1.24-1.48(\mathrm{n}=110 / 5)$, emptylooking or with one or a few minute guttules.

This is a common species, growing on both indigenous broadleaved trees, and exotic angiosperm and gymnosperm trees (Eucalyptus, Cupressus lusitanica) in montane forests. It may be a harmful pathogen, causing white-rot. The many collections from living Newtonia trees in the Usambara Mts. clearly indicate pathogenic characteristics, although this species seems to be less harmful than P. newtoniae. Phellinus senex (Nees \& Mont.) Imazeki is closely related to $P$. callimorphus, but it has more round and a little larger spores with a single, prominent guttule, and more strongly developed setae with regular base; it is common in East Africa, but we did not find it on Newtonia.

Specimens studied: On Newtonia buchananii: Tanzania. Tanga Reg.: Muheza Dist., Amani, on buttress of living tree in open forest, 24.II.2000 Mrema A6/1; on fallen dry branch in forest reserve, 24.II.2000 Mrema A10/9; Nilo - Amani, fallen dry branch in forest reserve, 24.II.2000 Mrema A11/10. Tanga Reg., Lushoto Dist., Mazumbai, on living tree, 15.XII.1995 Honkanen 783, $785,787,801$; on decayed trunk of $N$. buchananii, 15.XII.1995 Honkanen 788; on living tree between buttresses, 10.I.1998 Mrema T10/6, T 13/9, 12.I.1998 Mrema T40/19, 8.III.2000 Mrema M1/11, 10.III.2000 Mrema M16/15a.

Collections from other hosts: Tanzania. Arusha Reg., Arusha Dist., western Mt. Meru, Olmotonyi, cf. Cupressus lusitanica, 17.XII.1989 Niemelä 5337 \& Renvall 2323; C. lusitanica, 24.V.1988 Niemelä 4228 et al.; Entandrophragma excelsum (stoltzii), 13.XII.1988 Niemelä 4598 et al.; stump of an unidentified tree, 17.XII.1989 Niemelä 5333 et al.

Phellinus gilvus (Schwein. : Fr.) Pat.

Basidiocarp annual or perennial of a few years, shelf-shaped; cap 2-9 cm wide, 4-10 mm thick, projecting 1-5 cm. Upper surface cinnamon, pale pinkish brown or dark brown, variably rough or smooth: with felty tomentum or compact stiff hairs at least at base but sometimes all over, while margin usually glabrous, fairly smooth with small warts only; sometimes this smooth type covers most of the pileus. Edge sharp and thin, concolorous. Pore surface concolorous or a little darker than upper surface, pores 9-11 per mm. Section: Context thin, 1-3 mm, cinnamon coloured, soft corky but a little fibrous and lustrous on broken surface; tubes 2-3 mm long, concolorous.

Hyphal system dimitic, generative hyphae simple-septate; skeletal hyphae yellow-brown, 2.5-4 $\mu \mathrm{m}$ in diam., in context radially oriented but not quite parallel, subparallel in trama. Crystalbearing hyphae variably found at tube mouths. Hymenial setae brown, sharp-pointed, narrow, $(17-) 22-27(-30) \times 4-6(-7) \mu \mathrm{m}, \mathrm{L}=25.09 \mu \mathrm{m}, \mathrm{W}=$ $5.44 \mu \mathrm{m}, \mathrm{Q}=3.98-5.50(\mathrm{n}=39 / 6)$.

Basidiospores ellipsoid, thin-walled, hyaline, (3-)3.2-4.3(-4.7) $\times(2.1-) 2.3-2.9(-3.1) \mu \mathrm{m}, \mathrm{L}=$ $3.74 \mu \mathrm{m}, \mathrm{W}=2.64 \mu \mathrm{m}, \mathrm{Q}=1.30-1.56(\mathrm{n}=180 / 6)$.

There is great variation in collections referred to Phellinus gilvus. Our material has in general 
shorter and more round spores, and smaller pores, than in most descriptions in the literature. Two groups could be divided in our fairly scanty material: the 'montane variety' (collected in Mazumbai) has shorter spores ( $\mathrm{L}=3.36-3.57 \mu \mathrm{m})$ than the 'lowland variety' (from Amani and Solwezi, $\mathrm{L}=3.89-4.25 \mu \mathrm{m})$, spore thickness being the same. Evidently we are dealing with a complex of several sibling species. P. gilvus is mostly seen on dead tree trunks, stumps and big fallen branches in lowland and montane forests. Observations on Newtonia show that it is pathogenic to some extent.

Specimens studied: On Newtonia buchananii: Tanzania. Tanga Reg.: Muheza Dist., Amani, trunk of living tree in open forest, 24.II.2000 Mrema A5/6; Amani Nilo, dry branch in forest reserve, 6.III.2000 Mrema A16/19b. Tanga Reg., Lushoto Dist., Ndelemai, 9.I.1998 Mrema $C 6 / 3$; Mazumbai, on living tree between buttresses, in open forest, 8.III.2000 Mrema M18/12.

Collections from other hosts (only those specimens mentioned which were studied for spore measurements): Tanzania. Tanga Reg., Muheza Dist., Amani, on Maesopsis eminii, 9.XII.1988 Niemelä 4579 et al; fallen tree in rain forest, 9.XII.1988 Niemelä 4583 et al. Tanga Reg., Lushoto Dist., Mazumbai, fallen branch of unknown host, 8.XII.1989 Niemelä 5251 et al.; fallen branch in Ocotea/Syzygium dominated forest, 10.XII.1989 Niemelä 5293 et al,; decayed tree-trunk, 17.XII.1995 Honkanen 839. Zambia. Mwinilunga Dist., Solwezi, $350 \mathrm{~km}$ W of Solwezi town, Marquesia macroura, 2.II.1988 Niemelä 4126.

Phellinus sublaevigatus (Cleland \& Rodway) P.K. Buchanan \& Ryvarden - Fig. 5
Basidiocarp perennial, resupinate, woody hard, usually $0.5-1 \mathrm{~cm}$ thick but sometimes up to $4 \mathrm{~cm}$ thick (9-year-old basidiocarp). Sterile surface ('upper surface') above poroid area in basidiocarps growing on upright surface dark vinaceous brown or greyish brown, matted, fairly smooth, with indistinct horizontal zones. Sterile margin narrow, matted, cinnamon. Pore surface umber to clay buff, pale grey-brown or greyish sepia when not actively growing, pores $6-7(-8)$ per $\mathrm{mm}$. Section: Subiculum very thin, dark cinnamon coloured; tubes umber, clay buff or greyish brown, with very distinct annual layers, each layer $1-3$ $\mathrm{mm}$.

Hyphal system indistinctly dimitic (continuous transition from generative to skeletal hyphae), all hyphae simple-septate; skeletal hyphae pale yellow-brown in CB and IKI, bright red-brown in $\mathrm{KOH}, 2.8-3.6(-4) \mu \mathrm{m}$ in diam. $(\mathrm{n}=$ $15 / 1$ ), subparallel in both subiculum and trama. No encrusted hyphae at tube mouths, but rhomboid crystals developing in between hymenial cells in some specimens and becoming commoner deep in old tubes. Basidia subglobose, 14-15 $\times 8.5-10 \mu \mathrm{m}$, basidioles globose, $11-13 \times 8.5-10$ $\mu \mathrm{m}$, cystidioles with slightly thick-walled and yellowish basal swelling (4.5-9 $\mu \mathrm{m}$ diam.), and narrow (1-2 $\mu \mathrm{m}$ diam.), up to $30 \mu \mathrm{m}$ long neck, found in non-fertile hymenium. Hymenial setae almost absent in some sections, abundant in others, brown, sharp-pointed, narrow, (14-)16-26 $(-31) \times(3.5-) 4-6.5(-7.5) \mu \mathrm{m}, \mathrm{L}=20.35 \mu \mathrm{m}$, $\mathrm{W}=5.23 \mu \mathrm{m}, \mathrm{Q}=3.33-4.53(\mathrm{n}=40 / 3)$.

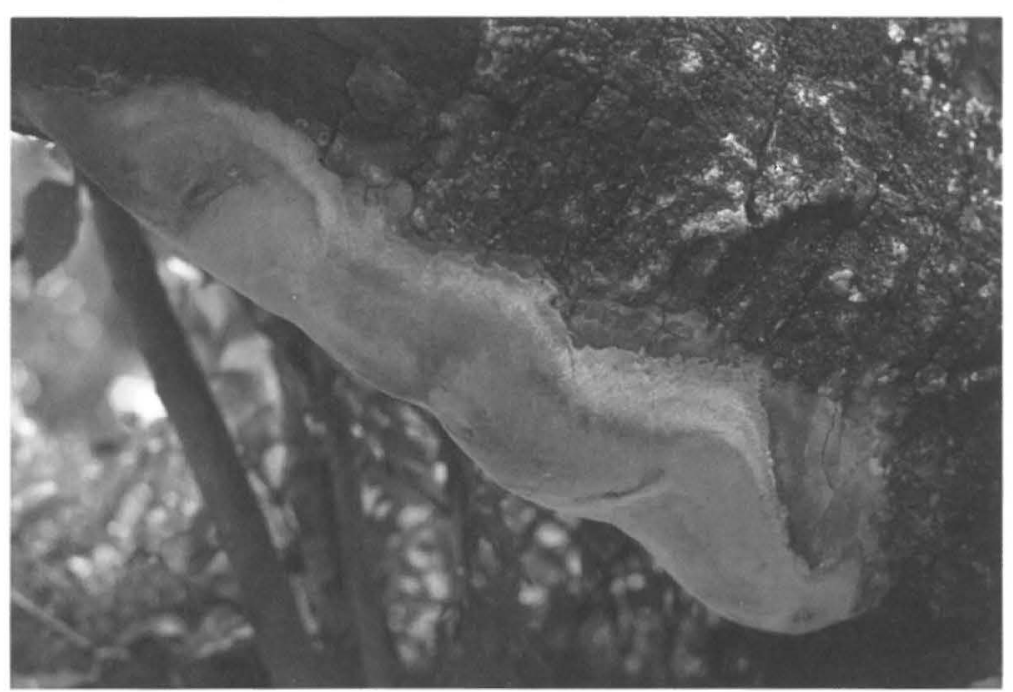

Fig. 5. Old basidiocarp of Phellinus sublaevigatus (Cleland. \& Rodway) P.K. Buchanan \& Ryvarden. Mount Meru, Arusha Nat. Park, 18.XII.1988 Niemelä 5157, photo TN. 
Basidiospores subglobose, thick-walled, hyaline, strongly dextrinoid, very strongly $\mathrm{CB}+,(5-)$ 5.3-7.5(-8.2) $\times(4.3-) 4.6-6.7(-7.4) \mu \mathrm{m}, \mathrm{L}=6.26$ $\mu \mathrm{m}, \mathrm{W}=5.46 \mu \mathrm{m}, \mathrm{Q}=1.10-1.20(\mathrm{n}=90 / 3)$, rapidly deteriorating and often eroded in specimens.

New to Africa. Buchanan and Ryvarden (1993) reported $P$. sublaevigatus from Australia. This belongs to the $P$. robustus complex and differs from the closest relative P. punctatus (P. Karst.) Pilát by having setae. The related, setae-bearing P. sonorae Gilb. and P. pseudopunctatus A. David et al. were discussed by Buchanan and Ryvarden (1993). Spore size varies in our specimens, being smallest $(\mathrm{L}=5.80 \mu \mathrm{m}, \mathrm{W}=4.84 \mu \mathrm{m})$ in the collection from Newtonia and largest $(\mathrm{L}=7.08$ $\mu \mathrm{m}, \mathrm{W}=6.18 \mu \mathrm{m})$ in the specimen from Ilex. Otherwise all they are alike.

Specimens studied: On Newtonia buchananii: Tanzania. Tanga Reg., Lushoto Dist., Mazumbai, on living tree, side of a buttress, 8.III.2000 Mrema M7/3.

Collections from other hosts: Tanzania. Arusha Reg., Arusha Dist., eastern Mt. Meru, Arusha Nat. Park, alt. $1970 \mathrm{~m}$, at base of living Ilex mitis, 7.I.1971 Niemelä 417a; standing dead tree, basidiocarps along 5 $\mathrm{m}$ on the trunk, 17.XII.1988 Niemelä 5152 et al.; large fallen tree, basidiocarps along 4-6 m on lower side of the trunk, 18.XII.1988 Niemelä 5157 et al.

\section{Phellinus wahlbergii (Fr.) D.A. Reid}

Basidiocarp perennial, shelf-shaped or triquetrous; cap usually $3-8 \mathrm{~cm}$ wide, $7-10 \mathrm{~mm}$ thick, projecting $1.5-7 \mathrm{~cm}$, but seldom reaching a high age and large dimensions. Upper surface dark cinnamon, sulcate with narrow zones, at first with velvety tomentum, later rough but with no crust, often covered with moss. Edge sharp, fairly thin, concolorous. Pore surface a little darker than upper surface, pores (5-)6-7 per mm. Section: Context thin, 1-3 mm, cinnamon coloured, soft corky; tubes concolorous, corky and easy to cut, $1-4 \mathrm{~mm}$ long per year (season), annual layers distinct.

Hyphal system dimitic, generative hyphae simple-septate, 2-2.5 $\mu \mathrm{m}$ in diam.; skeletal hyphae orange-brown, with capillary lumen, 1.9-3 $\mu \mathrm{m}$ in diam., interwoven in context, spaced interwoven in upper trama, more subparallel in lower parts close to tube mouths. Crystal-bearing hyphae common at tube mouths. Hymenial setae red-brown, subulate or narrow ventricose, with sharp and often hook-curved apex, (29-)32-44 $(-50) \times(6-) 6.5-9.5(-11) \mu \mathrm{m}, \mathrm{L}=36.60 \mu \mathrm{m}, \mathrm{W}=7.68$ $\mu \mathrm{m}, \mathrm{Q}=4.41-5.02(\mathrm{n}=30 / 3)$.
Basidiospores subglobose, fairly thin-walled, hyaline, IKI-, slightly $\mathrm{CB}+,(3.8-) 4-5.1(-5.5) \times$ (3.1-)3.2-4.1(-4.2) $\mu \mathrm{m}, \mathrm{L}=4.58 \mu \mathrm{m}, \mathrm{W}=3.67 \mu \mathrm{m}$, $\mathrm{Q}=1.22-1.27(\mathrm{n}=90 / 3)$.

Tube trama of $P$. wahlbergii is softer than in most other African Phellinus species, and it is easy to cut it with a razor blade. A collection from Newtonia (Mrema M15/7b) differs from the others in being thicker ( $2 \mathrm{~cm}$, with 5 annual layers in tubes), nodulose resupinate, and having smaller spores $(\mathrm{L}=4.11 \mu \mathrm{m}, \mathrm{W}=3.31 \mu \mathrm{m})$ and narrower setae $(\mathrm{L}=36.09 \mu \mathrm{m}, \mathrm{W}=7.27 \mu \mathrm{m})$, always with a bent tip. The other listed specimens are thin (0.6$1 \mathrm{~cm}$ at base), clearly pileate, with slightly larger spores $(\mathrm{L}=4.81 \mu \mathrm{m}, \mathrm{W}=3.85 \mu \mathrm{m})$ and the setae have a more strongly swollen base $(\mathrm{L}=36.85 \mu \mathrm{m}$, $\mathrm{W}=7.89 \mu \mathrm{m})$ and there are straight-tipped setae among the curved ones. The hyaline, cyanophilous spores and the crystal-bearing hyphae at dissepiment edges show that this species belongs to the P. torulosus (Pers.) Bourdot \& Galzin complex (= Phellinus subg. Fuscoporia (Murrill) Y.C. Dai; Dai 1999 and pers. comm.).

Sometimes, when growing on old living trees, $P$. wahlbergii may grow several decades old and become very large. One of our specimens (Niemelä 5283) was approximately $55 \mathrm{~cm}$ wide, projecting $30 \mathrm{~cm}$, and being $10 \mathrm{~cm}$ thick at base.

Specimens studied: On Newtonia buchananii: Tanzania. Tanga Reg., Lushoto Dist., Mazumbai, between buttresses, 9.I.1998 Mrema T2/1, 11.I.1998 Mrema T33/16, on buttress of a living tree, 8.III.2000 Mrema M15/7b.

Collections from other hosts: Tanzania. Tanga Reg., Lushoto Dist., Mazumbai, alt. 1350-1500 m, between buttresses of large, living Syzygium guineense, 9.XII.1989 Niemelä 5283; stump of S. guineense, 15.XII.1995 Honkanen 791; fallen trunk, 15.XII.1995 Honkanen 810a; root of living tree, 16.XII.1995 Honkanen 828.

\section{Ganoderma australe (Fr.) Pat. sensu lato}

Basidiocarp perennial; pileus applanate, with constricted base, very hard, $13 \mathrm{~cm}$ wide, $5 \mathrm{~cm}$ thick, projecting $9 \mathrm{~cm}$. Upper surface very hard, with dark brown crust, sulcate, not shining even when young. Edge fairly round, hard, brown. Pore surface white with greyish-brown tint or yellowish towards the margin, bruised areas turning instantly black-brown; pores 5-6 per mm. Section: Crust hard and glassy, 1-1.5 mm, black; context dark red-brown, woody, 5-15 mm thick; tubes concolorous, annual layers distinct but not separated by contextual layers. 
Hyphal system dimitic with skeleto-binding hyphae; generative hyphae with clamps. Skeleto-binding hyphae in context and trama dark redbrown, subsolid; apical parts divided into whiplike branches. Crust with interwoven and tightly packed hyphae, surface with a palisade of solid, red-brown hyphae, some clavate but most of them with a dichotomously forked double apex.

Basidiospores broad ovoid, brown, with a double wall and apical 'bubble' of exosporium sac (not included in measurements, mostly collapsed), ornamented and looking like asperulate, (9-)9.3-10.4(-11.2) × (6-)6.2-7.3(-7.5) $\mu \mathrm{m}, \mathrm{L}=$ $9.97 \mu \mathrm{m}, \mathrm{W}=6.76 \mu \mathrm{m}, \mathrm{Q}=1.48(\mathrm{n}=30 / 1)$.

Only one collection of this species was found on Newtonia, but we have several observations of it from East Africa on other hosts (not listed here). The species differs from Ganoderma boninense Pat. in having a non-laccate, ca. $1 \mathrm{~mm}$ thick crust, very dark red-brown context and tubes, and more distinctly perennial habit. The pileus is often covered with cocoa-coloured spore dust.

Specimen studied: On Newtonia buchananii: Tanzania. Tanga Reg., Lushoto Dist., Mazumbai Forest Reserve, on decayed fallen branch, 9.I.1998 Mrema T2/2.

\section{Ganoderma boninense Pat. sensu lato}

Basidiocarp annual or perennial; pileus applanate or triquetrous, sometimes with constricted base and even stipitate, hard, 4-15 cm wide, $1-4 \mathrm{~cm}$ thick, projecting 3-10 cm. Upper surface with dark reddish brown cuticle, sulcate or fairly smooth, when young shining as if laccate or freshly varnished. Edge round or sharp, hard, white and turning brown where bruised, in old fruit bodies concolorous with upper surface. Pore surface cream-coloured or yellowish, bruised areas turning instantly dark brown; pores 6-7 per mm. Stipe, when present, ca. $1 \mathrm{~cm}$ thick and up to $5 \mathrm{~cm}$ long, eccentric in specimens studied by us, with cuticle similar to that of the pileus. Section: Cuticle hard, $<1 \mathrm{~mm}$, almost black; context brown, hard felty or woody, up to 3 $\mathrm{cm}$ thick; tube layer concolorous, annual layers indistinct.

Hyphal system dimitic with skeleto-binding hyphae; generative hyphae with clamps. Skeleto-binding hyphae in context pale greyish brown, dextrinoid, $\mathrm{CB}+$, subsolid, in trama dark red-brown; apical parts divided into whip-like branches. Cuticle with dense palisade of antlershaped or knotty, very thick-walled hyphae, yellow, amyloid, slightly $\mathrm{CB}+$.

Basidiospores ovoid, pale brown in $\mathrm{KOH}$, dextrinoid, $\mathrm{CB}+$ (esp. when young), with a double wall and apical 'bubble', ornamented and looking like asperulate, (9.2-)9.6-11.2(-11.7) $\times$ (5.5-)5.7-6.9(-7.3) $\mu \mathrm{m}, \mathrm{L}=10.33 \mu \mathrm{m}, \mathrm{W}=6.24 \mu \mathrm{m}$, $\mathrm{Q}=1.63-1.68(\mathrm{n}=90 / 3)$.

This seems to be the second most serious pathogen of Newtonia, after Phellinus newtoni$a e$, causing butt-rot on living trees. Our material from Newtonia (except one G. australe, above) belongs to Ganoderma boninense in the sense of Núñez \& Ryvarden (2000), characterized by warted and branched, sklerified hyphae of the cuticle; those hyphae are strongly amyloid, especially if studied in heated IKI solution. The collections vary widely in their morphology. The spores above are slightly shorter, and about $1 \mu \mathrm{m}$ narrower than in East Asian specimens (Núñez \& Ryvarden 2000). We do not know if our African materials are exactly identical with the type, or if we are dealing with a species complex; an overview by Moncalvo and Ryvarden (1997) summarizes the magnitude of names addressed to the Ganodermataceae, and the difficulty in defining the species. Ganoderma boninense was described from Japan, and to our knowledge has not been reported from Africa before.

Specimens studied: On Newtonia buchananii: Tanzania. Tanga Reg., Muheza Dist., Amani, fallen dry branch, 24.II.2000 Mrema A7/2, A8/7; Amani - Derema, fallen dry branch in open forest, 22.II.2000 Mrema $A 2 / 5 b, A 4 / 3$; fallen dry tree in open forest, 22.II.2000 Mrema A3/4; Amani - Nilo Forest Reserve, fallen dry tree, 6.III.2000 Mrema A12/11; Amani Forest Reserve, between living buttresses, 25.III.2000 Mrema A14/13. Tanga Reg., Lushoto Dist., Mazumbai, between buttresses of living tree, 4.III.2000 Mrema M5/5; on fallen tree between buttresses, 8.III.2000 Mrema M6/8; on living trunk, 9.III.2000 Mrema M19/14.

\section{Fibroporia gossypium (Speg.) Parmasto}

Basidiocarp annual, resupinate, fragile, when fresh white, in dry condition cream-coloured. Sterile margin cottony soft, up to $10 \mathrm{~mm}$ wide. Pores angular, 3-4 per mm, tube mouths lacerate in some areas. Section: Subiculum cottony, white, $<1 \mathrm{~mm}$ thick; tube walls very thin, translucent as if oily, cream-coloured.

Hyphal system in subiculum dimitic with thinwalled generative hyphae, septate and having 
clamp connections, and skeletal hyphae $3-5 \mu \mathrm{m}$ in diam., subsolid, refractive, IKI-, CB-. Tube trama monomitic with fairly thin-walled generative hyphae, frequent septa and conspicuous clamps.

Basidiospores ellipsoid with abruptly rounded (truncate) ends, fairly thick-walled, IKI-, CB+ (reaction weak but distinct), (4.1-)4.3-5.3(-5.6) $\times$ (2.3-)2.5-3(-3.1) $\mu \mathrm{m}, \mathrm{L}=4.82 \mu \mathrm{m}, \mathrm{W}=2.74 \mu \mathrm{m}, \mathrm{Q}=$ $1.75-1.77(n=60 / 2)$.

Our two East African collections match well with the materials from Europe, in both spore characteristics and hyphal structure. This is a decayer of extensively rotten woody remnants, and is not very exact as to its hosts, which may be either gymnosperm or angiosperm trees. Typical features of $F$. gossypium are the dimitic subiculum $v s$. monomitic tube trama, and slightly thickwalled spores, which turn pale blue in Cotton Blue, and have blunt ends. The species is often filed under the genus Antrodia, but the very fragile structure and, in particular, peculiar spore characteristics support its transfer to the genus Fibroporia Parmasto, together with $F$. vaillantii (DC. : Fr.) Parmasto, F. norrlandica (Berglund \& Ryvarden) Niemelä and $F$. radiculosa (Peck) Parmasto.

Specimens studied: On Newtonia buchananii: Tanzania. Tanga Reg., Lushoto Dist., Mazumbai, decayed fragments of fallen trunk, 15.XII.1995 Honkanen 793.

Collection from another host: Tanzania. Arusha Reg., Arusha Dist., western slope of Mt. Meru, Laikinoi, alt. 1900-1950 m, stump of Pinus patula in plantation, 15.XII.1989 Niemelä 5308.
Microporus affinis (Blume \& Nees : Fr.) Kuntze -Fig. 6

Basidiocarp annual, or living for a few seasons, stipitate, substipitate, fan- or shelf-shaped, when dry woody, pilei 3-10 $\mathrm{cm}$ wide, 2-4 mm thick, projecting 3-9 cm, growing single or gregarious. Upper surface with sharp-lined zones, glabrous or in some zones velvety tomentose, purplebrown, yellow-brown and/or with greenish tints in tomentose zones. Edge sharp but not very thin, regular, at first cream-coloured, later concolorous with upper surface; quite stiff when dry. Pore surface cream, pores extremely small, 7-9 per $\mathrm{mm}$; sterile margin bordering the edge 1-2 mm wide, distinct. Stipe lateral, short or up to $3 \mathrm{~cm}$, $0.4-1 \mathrm{~cm}$ thick, concolorous with upper surface, with no white mycelium, attached to wood with disc-like foot. Section: All parts white, woody; black-brown line (cuticle) extremely thin, on the very surface, hardly seen without a lens.

Hyphal system trimitic, generative hyphae with clamps. Cuticle 25-50 $\mu \mathrm{m}$ thick, with orange-brown hyphae; from it glassy hyaline, thick (5-8 $\mu \mathrm{m})$ and thick-walled tomentum hyphae abruptly arise; in context skeletal hyphae subparallel, 4-6 $\mu \mathrm{m}$ in diam., binding hyphae found all over but abundant in lower parts. Trama with tightly interwoven hyphae.

Basidiospores ellipsoid or short cylindric, thin-walled, CB-, IKI-, (3.2-)3.3-4(-4.2) $\times(1.5-)$ $1.7-2(-2.2) \mu \mathrm{m}, \mathrm{L}=3.69 \mu \mathrm{m}, \mathrm{W}=1.88 \mu \mathrm{m}, \mathrm{Q}=1.84$

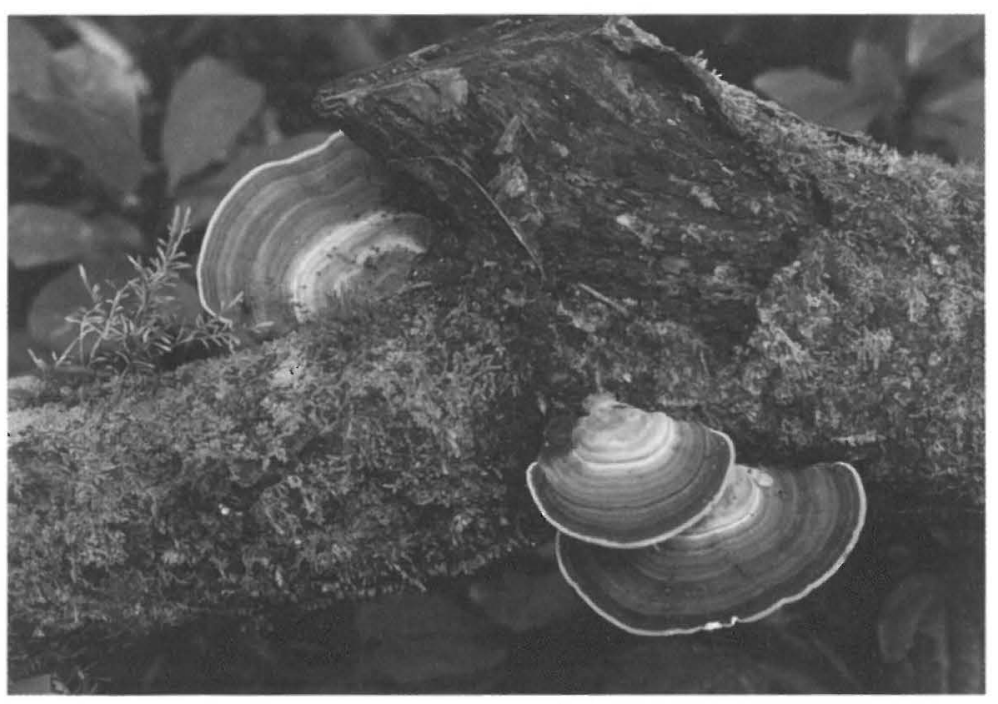

Fig. 6. Microporus affinis (Blume \& Nees : Fr.) Kuntze. Mazumbai, 21.V.1988 Niemelä 4216, photo TN. 
$2.04(n=68 / 3)$, more roundish than in the other African species of the genus.

This is the most sturdy species of Microporus, a genus characterized by elegant-looking, brightly coloured basidiocarps, which often have at least a minute stipe, and very small pores. Microporus affinis is a harmless, saprotrophic white-rotter on stumps, fallen trunks and branches, in both montane forests and miombo woodlands. It is very common and often collected because of the nice shape and beautiful colours.

Specimens studied: On Newtonia buchananii: Tanzania. Tanga Reg., Muheza Dist., Amani, fallen branch in open forest, 24.II.2000 Mrema A9/8. Tanga Reg., Lushoto Dist., Mazumbai, on decayed fallen branch, 9.I.1998 Mrema $T 2 / 2$.

Collections from other hosts (only those specimens mentioned which were studied for spore measurements): Tanzania. Tanga Reg., Muheza Dist., Amani, fallen trunk of unknown tree in cardamon plantation, 11.I.1971 Niemelä s.n.; unknown tree trunk in rainforest, 19.V.1988 Niemelä 4182 et al.; fallen branch in submontane rainforest, 11.XII.1995 Niemelä 5934 et al. Tanga Reg., Lushoto Dist., Mazumbai, fallen trunk of unknown tree in virgin lower montane forest, 21.V.1988 Niemelä 4216 et al.

\section{Perenniporia tephropora (Mont.) Ryvarden}

Basidiocarp perennial, resupinate, woody hard, finally rather thick and pulvinate. Sterile margin distinct, ochraceous cream-coloured. Poroid area smooth, ash grey, pores round, 5-6 per mm. Section: Subiculum felty and soft to cut, sepia brown or almost black, ca. $1 \mathrm{~mm}$ thick; tube layer grey-brown but paler at tube mouths.

Hyphal system dimitic with thin-walled generative hyphae, septate and having clamp connections; skeletal hyphae thick-walled, dextrinoid and $\mathrm{CB}+$, in subiculum $3.5-4.5(-5) \mu \mathrm{m}$ in diam., grey-brown, with spaced interwoven texture, in tube trama 3-6(-7) $\mu \mathrm{m}$ in diam., subparallel, often with medallion- or lens-like inflated sections, especially close to dissepiment edges.

Basidiospores ellipsoid with abruptly rounded (truncate) ends, fairly thick-walled, slightly dextrinoid (contents pink), $\mathrm{CB}+,(4.5-) 4.7-5.3$ $(-5.8) \times(3-) 3.1-4 \mu \mathrm{m}, \mathrm{L}=4.97 \mu \mathrm{m}, \mathrm{W}=3.54 \mu \mathrm{m}, \mathrm{Q}=$ $1.40(\mathrm{n}=30 / 1)$.

Ryvarden and Johansen (1980) reported this species from East Africa. Our material agrees well with the description in that book, as well as in Núñez \& Ryvarden (2000) and Parmasto \& Hallenberg (2000); Dai et al. (2002), while studying
Chinese material, reported the skeletal hyphae to be non-dextrinoid. In our East African specimen they are bright brick-red in IKI; also their cyanophilous reaction is very strong.

Specimens studied: On Newtonia buchananii: Tanzania. Tanga Reg., Lushoto Dist., Mazumbai, 15.XII.1995 Honkanen 803; at base between buttresses, 10.I.1998 Mrema T12/8.

\section{Concluding remarks}

Anthropogenic disturbance seems to be the major single reason altering the species diversity and functioning of fungal communities in the studied forest ecosystems. Timber harvesting (even when carried out decades ago), fuelwood collection and uncontrolled fires create absence of certain kinds of woody substrate in the forest. Differences in this respect are discussed below.

The Amani Nature Reserve. Collection of basidiocarps in the Amani Reserve was not easy because they were fairly scanty on Newtonia trees. The studied areas were previously logged and were then let to recover. Although the sites now looked like intact, the young age of Newtonia individuals still obscured the observation of their pathogens. Anthropogenic disturbance including timber harvesting explains why smaller trees dominated the area if compared to the situation in Mazumbai, West Usambara Mts. Fuelwood collection by local people is allowed once a week; reduced substrate may have contributed to the observed low number of basidiocarps particularly on fallen branches. Anyhow, basidiocarps were collected from stems, between buttresses and even high up in the branches of living trees, and also from fallen branches. More than half $(63 \%)$ of the fungi were collected on dead wood suggesting that any pathogenic fungus identified could as well live as saprotroph.

The Mazumbai Forest Reserve. Entering and fuelwood collecting in the Mazumbai Reserve is not allowed at all. Much more fungi were growing on Newtonia in Mazumbai if compared to those in East Usambara. Thick trees $>70 \mathrm{~cm}$ in diameter were repeatedly observed in the Reserve, as well as fallen large trees, thus creating open gaps in the forest. Newtonia buchananii was commoner in Mazumbai than in Amani. Most fungal basidiocarps were found on living trees. The more the buttresses, the more likely it was to find fungal pathogens. Some buttresses reached 13 metres 
high up from the ground. The major pathogen of Newtonia in Mazumbai Reserve was Phellinus newtoniae, followed by Ganoderma boninense; over $80 \%$ of the fruit bodies were collected from living trees, and more than half $(55 \%)$ of them were found either on buttresses or on the trunk between them; this clearly suggests root and butt rot problems, and is obviously linked with the cracks and cankers reported on Newtonia in an earlier paper (Mrema \& Nummelin 1998). Even if the observed wounds during formation of buttresses were not the infection route for pathogenic fungi, they may indirectly influence the activity of the fungus inside the tree's sapwood and heartwood.

Observations were also made elsewhere in West Usambaras outside the Reserve, in areas where fuelwood collecting is allowed, e.g., Ndelemai. Very few basidiocarps were noted in these human disturbed forests, confirming our hypothesis in East Usambara that anthropogenic disturbance affects the species diversity of fungi living on Newtonia buchananii. Fuelwood collecting diminishes in particular the numbers of harmless saprotrophs living on thin woody debris, while timber harvesting decreases the amount of basidiocarps on living trees. This, however, does not mean a more healthy forest, but only tells that the young age of trees does not yet reveal the presence of slow-growing fungi in their inner wood and roots. Phellinus cf. rimosus was often found in such disturbed forests.

Our results show that the fungi attacking Newtonia buchananii clearly differ from those on Ocotea usambarensis and Hagenia abyssini$c a$ of the same area, East Africa. On Newtonia the greatest decay damages are caused by species of the Phellinus rimosus complex and genus Ganoderma. Perenniporia (Loweporus) inflexibilis (Berk.) Corner, Phellinus apiahynus (Speg.) Rajchenb. \& J.E. Wright and $P$. senex are the main decayers of Ocotea usambarensis (Renvall \&
Niemelä 1993, Nsolomo \& Venn 2000), while Hagenia is mainly infested by Hymenochaete ochromarginata P.H.B.Talbot (Niemelä et al. 1998).

Recently the genus Phellinus was divided into several more natural genera (Fiasson \& Niemelä 1984, Wagner \& Fischer 2001). This division is still incomplete, in particular in regard the tropical and other extra-European species, and in many cases a proposal of an updated genus cannot yet be made (Dai 1999). For this reason we are still using the old generic name Phellinus in a collective sense, and let further studies show what changes of genus will be needed. Some hints were anyhow given in the text.

During field study on Newtonia the author FAM collected a great number of other fungi, too, in particular in the Mazumbai Forest Reserve. A Xylobolus (stereoid Aphyllophorales) and some pyrenomycetous ascomycetes were found on the trees, and mycelia were isolated from decayed wood. It is hoped that this extensive material can be identified and published in the future. Many isolated mycelial strains seem to belong to endophytic fungi, whose identification certainly is a time-consuming challenge.

Acknowledgements: Dr. Matti Nummelin (Helsinki) inspired the preparation of this study and accompanied FAM in the field. An expert of African forest flora, Prof. Tamás Pócs (Eger) was an invaluable guide during some field trips with TN and other mycologists from the University of Helsinki. Prof. Yu-Cheng Dai (Helsinki \& Shenyang) is thanked for his notes on the Phellinus species; he also gave some specimens for us to compare. Prof. Teuvo Ahti kindly revised the Latin. Our thanks are due to the Sokoine University of Agriculture, Faculty of Forestry, for allowing us to carry out the study at the Mazumbai Forest Reserve; Mr. Modest Mrecha, M.For., is specially thanked for providing all necessary help during our visits to Mazumbai. Dr. Pertti Renvall (Kuopio) and Mr. Jarmo Honkanen, M.Sc. (Helsinki) identified many collections of TN, and among many others accompanied $\mathrm{TN}$ in field trips to Africa. Curators of the herbaria BPI, NY, PDD and S are thanked for loans of type and other specimens. The Finnish Mycological Society supported the colour printing of this paper. 


\section{References}

Anonymous 1969: Flora of British fungi, colour identification chart. - Royal Bot. Garden Edinburgh. 6 unnumbered $\mathrm{pp}$.

Brenan, J.P.M. 1959: Leguminosae subfamily Mimosoideae. - In: C.E. Hubbard \& E. Milne-Redhead (eds.), Flora of tropical East Africa. Crown Agents for Oversea Governm. Admin., London. 173 pp.

Bryce, J.M. 1967: The commercial timbers of Tanzania. - Tanzania Ministry of Agriculture and Co-operatives, Forest Division, Moshi. 139 pp.

Buchanan, P.K. \& Ryvarden, L. 1993: Type studies in the Polyporaceae 24, species described by Cleland, Rodway and Cheel. - Australian Syst. Bot. 6: 215235.

Cleland, J.B. 1935: The ecology of the aborigines of Central Australia, botanical notes. - Trans. \& Proc. Roy. Soc. South Australia 59: 113-124.

Coates Palgrave, K. 1990: Trees of Southern Africa. Struik, Cape Town. 959 pp.

Dai, Y.C. 1999: Phellinus sensu lato (Aphyllophorales, Hymenochaetaceae) in East Asia. - Acta Bot. Fennica 166: $1-115$.

Dai, Y.C., Niemelä, T. \& Kinnunen, J. 2002: The polypore genera Abundisporus and Perenniporia (Basidiomycota) in China, with notes on Haploporus. - Ann. Bot. Fennici 39: 169-182.

Fanshawe, D. 1971: The vegetation of Zambia. - Rep. Zambia Ministry Rural Dev. For. Res. Bull. 7: 1-67.

Fiasson, J.L. \& Niemelä, T. 1984: The Hymenochaetales, a revision of the European poroid taxa. Karstenia 24: 14-28.

Gilbertson, R.L. \& Ryvarden, L. 1986: North American polypores 1. Abortiporus to Lindtneria. - Fungiflora, Oslo. $433 \mathrm{pp}$

Hamilton, A.C. \& Bensted-Smith, R. 1989: Forest conservation in the East Usambara Mountains, Tanzania. - IUCN, Gland \& Ministry Lands Nat. Resourc. Tourism, Dar es Salaam. 392 pp.

Holmgren, P.K., Holmgren, N.H. \& Barnett, L.C. (eds.) 1990: Index herbariorum 2, the herbaria of the world. 8th ed. - New York Bot. Garden, Bronx. 693 pp.

Iversen, S.T. 1991: The Usambara Mountains, NE Tanzania, phytogrography of the vascular plant flora. Symb. Bot. Upsalienses 29(3): 1-234.

Keay, R.W.J. 1989: Trees of Nigeria. - Clarendon Press, Oxford. $476 \mathrm{pp}$.

Kotlaba, F. \& Pouzar, Z. 1978: Notes on Phellinus rimosus complex (Hymenochaetaceae). - Acta Bot. Croatica 37: 171-182.

Larsen, M.J. \& Cobb-Poulle, L.A. 1990: Phellinus (Hymenochaetaceae), a survey of the world taxa. - Synopsis Fungorum 3: 1-206.

Lock, J.M. 1989: Legumes of Africa. A check-list. Royal Bot. Gardens, Kew. 619 pp.

Lovett, J.C. 1996: Elevational and latitudinal changes in tree associations and diversity in the Eastern Arc mountains of Tanzania. - J. Tropical Ecol. 12: 629650.
Lowe, J.L. 1957: Polyporaceae of North America, the genus Fomes. - State Univ. Coll. Forestry Syracuse Univ. Techn. Publ. 80: 1-97.

Lundgren, B. 1978: Soil conditions and nutrient cycling under natural and plantation forests in Tanzanian highlands. - Swedish Univ. Agric. Sci., Forest Ecol. Forest Soils Rep. 31: 1-429.

Mabberley, D.J. 1990: The plant-book, a portable dictionary of the higher plants. - Cambridge Univ. Press, Cambridge. 707 pp.

Moncalvo, J.M. \& Ryvarden, L. 1997: A nomenclatural study of the Ganodermataceae Donk. - Synopsis Fungorum 11: 1-114.

Mrema, F.A. 2001: Abiotic and biotic factors influencing the performance of Leucaena leucocephala and Newtonia buchananii trees in Tanzania. - Acta Univ. Agric. Sueciae Silvestria 229: $1-24+5$ appendices (PhD thesis).

Mrema, F.A. \& Nummelin, M. 1998: Stem cracks and decay in Newtonia buchananii trees in the Mazumbai Forest Reserve, West Usambara Mountains, Tanzania. - J. East African Nat. Hist. 87: 327-338.

Niemelä, T., Renvall, P. \& Hjortstam, K. 1998: Hagenia abyssinica and its fungal decayers in natural stands. Edinburgh J. Bot. 55: 473-484.

Núñez, M. \& Ryvarden, L. 2000: East Asian polypores 1. Ganodermataceae and Hymenochaetaceae. - Synopsis Fungorum 13: 1-168.

Nsolomo, V.R. \& Venn, K. 1996: Decay fungi of Ocotea usambarensis Engl. trees in the Usambara and Kilimanjaro mountain rain forests. - In: Nsolomo, V.R., Fungal diseases of trees in Tanzania with emphasis on the stem decay of the East African camphor tree, Ocotea usambarensis Engl. PhD thesis, Agric. Univ. Norway, Ås.

Nsolomo, V.R. \& Venn, K. 2000: Capacity of fungi to colonise wood of the East African camphor tree, Ocotea usambarensis. - Mycol. Res. 104: 14681472.

Nsolomo, V.R., Venn, K. \& Solheim, H. 2000: The ability of some fungi to cause decay in the East African camphor tree, Ocotea usambarensis. - Mycol. Res. 104: 1473-1479.

Parmasto, E. \& Hallenberg, N. 2000: The genus Abundisporus (Hymenomycetes, Basidiomycotina). Karstenia 40: 129-138.

Petersen, J. 1996: Farvekort. - Foreningen til Svampekundskabens Fremme. 6 unnumbered pp.

Quanten, E. 1997: The polypores (Polyporaceae s.1.) of Papua New Guinea. - Opera Bot. Belgica 11: 1-352.

Rayner, R.W. 1970: A mycological colour chart. Commonwealth Mycol. Inst., Kew \& British Mycol. Soc. 34 pp. +17 tab.

Redhead, J.F. 1981: The Mazumbai forest, an island of lower montane rain forest in the West Usambaras. African J. Ecol. 19: 195-199.

Renvall, P. \& Niemelä, T. 1993: Ocotea usambarensis and its fungal decayers in natural stands. - Bull. Jard. Bot. Nat. Belgique 62: 403-414. 
Ruffo, C.K., Mmari, C., Kibuwa, S.P., Lovett, J., Iversen, S. \& Hamilton, A.C. 1989: A preliminary list of plant species recorded from the East Usambara forests. - In: Hamilton, A.C. \& Bensted-Smith, R. (eds.), Forest conservation in the East Usambara Mountains, Tanzania: 157-179. IUCN, Gland \& Ministry Lands Nat. Resourc. Tourism, Dar es Salaam. 392 pp.

Ryvarden, L. \& Johansen, I. 1980: A preliminary polypore flora of East Africa. - Fungiflora, Oslo. $636 \mathrm{pp}$.

Ryvarden, L. 1985: Type studies in the Polyporaceae 17, species described by W.A. Murrill . - Mycotaxon 23: $169-198$.

Schulman, L., Junikka, L., Mndolwa, A. \& Rajabu, I. 1998: Trees of Amani Nature Reserve, NE Tanzania. - Ministry Nat. Resourc. Tourism Tanzania, Dar es Salaam. 336 pp.
Suryanarayanan, T.S. \& Rajagopal, K. 2000: Fungal endophytes (phellophytes) of some tropical forest trees. - Indian Forester 126: 165-170.

Wagner, T. \& Fischer, M. 2001: Natural groups and a revised system for the European poroid Hymenochaetales (Basidiomycota) supported by nLSU rDNA sequence data. - Mycol. Res. 105: 773-782.

White, F. 1983: The vegetation of Africa. - UNESCO (Paris) Nat. Resources Res. 20: 1-356.

White, F., Dowsett-Lemaire, F. \& Chapman, J.D. 2001: Evergreen forest flora of Malawi. - Royal Botanic Gardens, Kew. 697 pp.

Wingfield, R.C. 1975: A first list, critical and annotated, of the plants of the Dar es Salaam University forest reserve at Mazumbai in the West Usambara Mountains. - Univ. Dar es Salaam Bot. Dept. Publ. 3: 1-6. van Wyk, B. \& van Wyk, P. 1997: Field guide to trees of Southern Africa. - Struik, Cape Town. 536 pp. 